\title{
Artificial Feeding as Stress Factor Affecting Wing Venation Symmetry of Worker Honeybees
}

Fathy, H. M. ${ }^{1}$; A. M. Mazeed ${ }^{2}$; E. A. Nafae ${ }^{3}$ and M. R. Abd EI Dayem ${ }^{3}$

${ }^{1}$ Department of Economic Entomology, Faculty of Agriculture, Mansoura University.

${ }^{2}$ Department of Economic Entomology and Pesticides, Faculty of Agriculture, Cairo University.

${ }^{3}$ Department of Apiculture, Plant Protection Research Institute, Agriculture Research Center, Dokki, Giza.

\section{ABSTRACT}

Directional and fluctuating asymmetry were estimated in worker bees fed on sugar syrups in comparison with feeding with honey (control). By using 25 traits of wing venation pattern on left and right forewing of worker honey bees, it could be stated that directional asymmetry (DA) was not related to the type of feeding. Fluctuating asymmetry (FA), however, differed between characters and between feeding treatments, but no interaction was found between them. The individual characters were combined and analyzed as composite fluctuating asymmetry to maximize the probability of detecting (FA)-stress relationship when it exists. The result showed that (FA) of distances between vein junctions were significantly higher in sugar-feeding than in honey-feeding colonies.

Keywords: Honeybees, workers, forewing venation, vein distance, vein angels, polar coordination, fluctuating asymmetry, directional asymmetry, composite fluctuating asymmetry.

\section{INTRODUCTION}

Nutrition is considered the first line of defense of honeybee colonies and is the key in dealing with major honeybee diseases. Honeybee Larvae fed on a nutritionally poor diet were found to be significantly more susceptible to various diseases (Foley, et al. 2012; Li, et al., 2007). In addition, Longevity of worker bees (Chengcheng, Xu, et al. 2014). and body size (Daly, et al. 1995) decrease when their larvae experience poor maturational conditions.

During development, individuals of an organism species may be exposed to unfavorable conditions which may impair optimal growth or some physiological functions (Møller and Thornhill 1998; Field and Yuval 1999; SchmidHempel 2003). So, they may be unable accurately to develop their expected phenotype given their genotype and the environment (Palmer and Strobeck 1986). Accordingly, departures from the ideal expression of particular traits are expected which could be used as evidence that organisms have been exposed to sub-optimal resources as mediated through environmental or genetic constraints (SchmidHempel, 2003).

Bee colonies suffer greatly from shortage of natural sources of nectars as well as hard conditions for foraging during winter. Beekeepers usually supply their colonies with artificial feeding during dearth periods of the year, especially cold times of winter. This is accomplished by feeding sucrose solution, invert sugars, high fructose solution or various fruit syrups (Neupane \& Thapa, 2005) inside the hive.

One of the most important morphological characteristics being used as stress-bioindicator for measuring developmental instability in many insects is wing fluctuating asymmetry (FA) (Parsons and Hoffmann 1991; Clarke and McKenzie 1992; Bjorksten et al. 2000; Rantala, et al 2004). So, the aim of our study was to show the possible effect of artificial feeding on the fore wing asymmetry of honeybee workers.

\section{MATERIALS AND METHODS}

This experiment was carried out in the Apiary of Beekeeping Research Center at the Ministry of Agriculture in 2016. The treatments were applied on 12 colonies belonging to Carniolan race (A.m carnica) each supplied with one kilogram of bee worker on 3 empty combs. The queens were all sisters and mated naturally in Manzala (where Carniolan bee are preserved purely) at the apiary from which the experimental colonies were prepared. The colonies were divided randomly into 4 groups each of three colonies, and were fed with different types of sugar nutrition: I Sugar Cane syrup: Sucrose-water solution 1:1.

II Sugar beet syrup: Sucrose-water solution 1:1.

III Sugar beet \& Citrus honey syrup: Honey-Sucrosewater solution $0.5: 0.5: 1$.

IV Citrus honey syrup (Control): Honey-water solution $1: 1$

Each colony was fed twice a week by one-liter solution. Each group was fed exclusively with its treatment for 6 weeks before taking of bee samples. From each colony in each group, a worker sealed brood comb was taken and put in a cage into their colony until emerging of worker bees, then about 15 workers were collected from each group and preserved in ethanol $70 \%$ until dissection.

From each honeybee worker, the pair of forewings was dissected, and then they were air-dried to the glass slides while ethanol evaporated, and the dry mounts were digitally photographed by a slide-scanner.

1. Asymmetry of wing venation:

The forewing measuring characters were chosen according to (Kauhausen 2002; Szymula, et al. 2010), who used polar coordinate system for description the location of the different intervenation points in terms of lengths and angles between these points. The number of points chosen was 17 (Fig. 1).

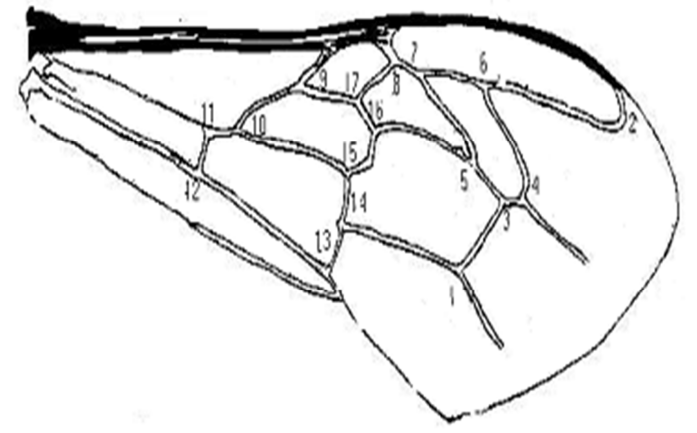

Fig. 1. Forewing of worker bees showing 17 points used to establish wing coordinates 
The first point has no values on the coordinate system $(\mathrm{X}=0$ and $\mathrm{Y}=0)$. The second point, however, was represented by one value on the first reference point. All the remaining points are represented by two values, so the number of the coordinates is $(2 \times 17)-3=31$ points, which represent the measured characters (Table, 1). The coordinates characters measured represent 16 intervention distances and 15 angles coordinates. For technical reasons and to ensure precision of the measurements values, 6 characters were excluded from the results.

Table 1. Characters measured on the forewing

\begin{tabular}{|c|c|c|c|c|c|}
\hline No & $\begin{array}{c}\text { Distance } \\
\text { (L) and } \\
\text { Angles (A) } \\
\text { between } \\
\text { coordinates }\end{array}$ & $\begin{array}{l}\text { Morphometrical } \\
\text { characters in } \\
\text { relation to the } \\
\text { first coordinates } \\
(1,2) \text { (Fig 1) }\end{array}$ & No & $\begin{array}{l}\text { Distance } \\
\text { (L) and } \\
\text { Angles (A) } \\
\text { between } \\
\text { coordinates }\end{array}$ & $\begin{array}{l}\text { Morphometrical } \\
\text { characters in } \\
\text { relation to the } \\
\text { first coordinates } \\
(1,2)(\text { Fig } 1) \\
\end{array}$ \\
\hline 1 & L1 & $1-2$ & 17 & A9 & $* 2-1-10$ \\
\hline 2 & L2 & $1-3$ & 18 & L10 & $* 1-11$ \\
\hline 3 & $\mathrm{~A} 2$ & $2-1-3$ & 19 & A10 & *2-1-11 \\
\hline 4 & L3 & $1-4$ & 20 & L11 & $* 1-12$ \\
\hline 5 & A3 & $2-1-4$ & 21 & A11 & $* 2-1-12$ \\
\hline 6 & L4 & $1-5$ & 22 & L12 & 1-13 \\
\hline 7 & A4 & $2-1-5$ & 23 & A12 & $2-1-13$ \\
\hline 8 & L5 & $1-6$ & 24 & L13 & $1-14$ \\
\hline 9 & A5 & $2-1-6$ & 25 & A13 & $2-1-14$ \\
\hline 10 & L6 & $1-7$ & 26 & L14 & $1-15$ \\
\hline 11 & A6 & $2-1-7$ & 27 & A14 & $2-1-15$ \\
\hline 12 & L7 & $1-8$ & 28 & L15 & $1-16$ \\
\hline 13 & A7 & $2-1-8$ & 29 & A15 & $2-1-16$ \\
\hline 14 & L8 & $1-9$ & 30 & L16 & $1-17$ \\
\hline 15 & A8 & $2-1-9$ & 31 & A16 & $2-1-17$ \\
\hline 16 & *L9 & $1-10$ & & & \\
\hline
\end{tabular}

\section{Equipment and measurement procedure}

The bees were prepared and the forewing characters were measured at Bee Section of Faculty of Agriculture, Cairo University.

The morphometrical system used consisted of the following parts:

1. Computer unit with a suitable analyzing program developed by Kauhausen (2002).

2. A Slide-Scanner (Minolta Dimâge Scan Dual 11).

The wing measurements were made by using a 35 $\mathrm{mm}$ slide projector to project the images of mounted wings onto a monitor screen. A particular type of slide known as a Gepe consists of two plastic half frames containing thin metal masks and each half frame is separately glazed.

From each honeybee worker, the left and right forewings were cut off at the base with a fine forceps and dry-mounted onto slides. Each slide bear 15 wings and each 4 slides were put in a slide mount holder, which was then put inside the Scanner, in order to scan the mounted wings. After setting a suitable display-program, the wings were displayed on the screen monitor of a computer, and by the computer-mouse, the different intervention points were marked. The measuring-program converted these coordinate points into actual lengths and angles of the different intervention points relative to the first two points. The converted measurements are then stored in a new file.
For every bee sample, the converted data, the information about its origin, the type of bees, to which it belongs, and the date of collection were registered in a data-bank.

\section{Statistical analysis:}

To obtain the measure of directional asymmetry (DA), paired t-test between left and right wing for each trait was carried out according to (Palmer 1994). Because we have several comparisons (31), and because the individual tests may not be independent, the decisions based on conventional levels of significance might be in doubt, so we employ a conservative approach in which one lower the type 1 error of the statistic of significance for each comparison so that the probability of making any type 1 error at all in the entire series of tests does not exceed $\alpha$. For all characters, a significant $p$ value was set at 0.002 based on Bonferroni's correction for 25 comparisons (Sokal \& Rohlf, 1995).

It was advised that characters that show directional asymmetry should not be used for analysis of fluctuating asymmetry, because its presence make the interpretation of fluctuating asymmetry more difficult, (Palmer and Strobeck 2003), so the characters showing (DA) in workers were excluded from our analysis when calculating (FA).

(FA) was calculated as (FA)1 of Palmer (1994), which is the (FA) measure reported in most of studies as the mean of absolute value of the difference in trait size between the right and the left sides of the body $|\mathrm{R}-\mathrm{L}|$.

To test the significance of AF between the four groups, we carry out a significance test for absolute asymmetry difference by using two-way ANOVA, to test the effect of both traits and feeding treatments on the value of (FA)

After doing individual tests, individual data of absolute asymmetry were pooled to make composite variable of all 25 variables (Clarke and McKenzie 1992; Whitlock 1993; Leung, et al. 2000; Mazeed, et al 2015). The composite variable is the sum of absolute (FA) values for all traits for each individual. Absolute (FA) values are used because (FA) of individuals should be directionally random, and it is the magnitude of asymmetry in either direction that may indicate stress. The new composite variable was analyzed by using t-test. All the analyses were carried out by using AlmoStatistik-System, Version 15 (Holm, 2015).

\section{RESULTS AND DISCUSSION}

\section{Testing of directional asymmetry (DA):}

The results of T-Paired test of 25 characters in the four groups are shown in table (2). In worker bees, and from 25 characters measured, 3 characters showed significant differences between left and right wing. Two of them were in favor of the right wing (L1 and A6) and one in favor of left wing (A7). In sugar cane syrup, and one character in sugar beet syrup shoed (DA) in favor of left wing (A6), suggesting the presence of directional asymmetry (DA) in data. 
Table 2. Effect of different feeding on directional asymmetry of the forewing venation characters of worker honey bees (T Paired Test)

\begin{tabular}{|c|c|c|c|c|c|c|c|c|}
\hline \multirow{2}{*}{$\begin{array}{l}\text { Venation } \\
\text { characters }\end{array}$} & \multicolumn{2}{|c|}{ Sugar Cane feeding } & \multicolumn{2}{|c|}{ Sugar Beet feeding } & \multicolumn{2}{|c|}{ Sugar Beet \& Citrus honey feeding } & \multicolumn{2}{|c|}{ Citrus honey feeding } \\
\hline & $\begin{array}{c}\text { t- } \\
\text { value }\end{array}$ & $\begin{array}{c}\text { Sig. } \\
\text { (2-tailed) }\end{array}$ & $\begin{array}{c}\mathrm{t}- \\
\text { value }\end{array}$ & $\begin{array}{c}\text { Sig. } \\
\text { (2-tailed) }\end{array}$ & $\begin{array}{c}\mathrm{t}- \\
\text { value }\end{array}$ & $\begin{array}{c}\text { Sig. } \\
\text { (2-tailed) }\end{array}$ & $\begin{array}{c}\text { t- } \\
\text { value }\end{array}$ & $\begin{array}{c}\text { Sig. } \\
\text { (2-tailed) }\end{array}$ \\
\hline L1 & $3.937^{*}$ & .001 & 1.317 & 0.204 & 2.351 & 0.029 & 0.515 & 0.616 \\
\hline L2 & 0.736 & 0.468 & -0.325 & 0.749 & -0.719 & 0.480 & 0.000 & 1.000 \\
\hline $\mathrm{A} 2$ & 1.259 & 0.219 & 0.619 & 0.544 & -0.987 & 0.335 & 0.214 & 0.834 \\
\hline L3 & 0.902 & 0.375 & 0.314 & 0.757 & -0.118 & 0.908 & 1.100 & 0.293 \\
\hline A3 & 1.495 & 0.147 & 1.380 & 0.185 & 0.271 & 0.789 & 1.652 & 0.124 \\
\hline $\mathrm{L} 4$ & 2.791 & 0.010 & 1.661 & 0.114 & -1.872 & 0.076 & -0.493 & 0.631 \\
\hline A4 & 0.911 & 0.371 & -0.678 & 0.506 & -1.374 & 0.185 & -1.107 & 0.290 \\
\hline L5 & -0.328 & 0.746 & -0.615 & 0.546 & 0.116 & 0.909 & -0.877 & 0.398 \\
\hline A5 & -2.449 & 0.021 & -1.661 & 0.114 & 0.740 & 0.468 & -0.574 & 0.577 \\
\hline L6 & 0.440 & 0.663 & -0.775 & 0.448 & -3.619 & 0.002 & -0.615 & 0.550 \\
\hline A6 & $5.443 *$ & 0.000 & $-3.741 *$ & 0.001 & -2.250 & 0.036 & -0.581 & 0.572 \\
\hline L7 & -0.542 & 0.592 & -0.884 & 0.388 & -1.376 & 0.184 & -1.514 & 0.156 \\
\hline A7 & $-3.797 *$ & 0.001 & -2.257 & 0.037 & 0.856 & 0.402 & -0.004 & 0.997 \\
\hline L8 & 1.213 & 0.236 & 0.134 & 0.895 & -1.210 & 0.240 & -0.656 & 0.524 \\
\hline A8 & -1.589 & 0.124 & -1.070 & 0.299 & 1.421 & 0.171 & -0.108 & 0.916 \\
\hline L12 & 0.049 & 0.961 & -0.417 & 0.682 & 0.920 & 0.368 & 0.000 & 1.000 \\
\hline A12 & -2.712 & 0.012 & -1.479 & 0.156 & 2.994 & 0.007 & -0.523 & 0.610 \\
\hline L13 & 1.433 & 0.164 & -0.297 & 0.770 & -0.603 & 0.553 & -0.610 & 0.553 \\
\hline A13 & -2.048 & 0.051 & -1.281 & 0.217 & 2.119 & 0.047 & -0.477 & 0.642 \\
\hline L14 & 0.166 & 0.869 & -0.071 & 0.944 & 0.072 & 0.943 & -0.399 & 0.697 \\
\hline A14 & -1.511 & 0.143 & -1.137 & 0.271 & 0.745 & 0.465 & -0.442 & 0.666 \\
\hline L15 & 3.218 & 0.003 & 0.218 & 0.830 & 1.770 & 0.092 & 0.693 & 0.502 \\
\hline A15 & -2.334 & 0.028 & -0.733 & 0.473 & 0.808 & 0.428 & 0.252 & 0.805 \\
\hline L16 & 2.935 & 0.007 & 1.157 & 0.263 & 0.277 & 0.785 & 0.000 & 1.000 \\
\hline A16 & -2.324 & 0.028 & -0.904 & 0.378 & 1.962 & 0.064 & -0.121 & 0.906 \\
\hline
\end{tabular}

2. Fluctuating asymmetry (FA).

Results from two-way ANOVA test that combine information from different characters to test the difference in (FA) among feeding groups are shown in table (3).

As shown in table (3) and concerning (FA) in workers the different characters has a significant effect on the value of (FA). Also, the feeding-type has a significant effect on the value of (FA). No Interaction was found between traits and feeding groups.

Table 3. ANOVA table for analyzing the effect of trait and feeding treatment on FA of forewing venation in workers

\begin{tabular}{lccc}
\hline S. V & df & MS & F \\
\hline Traits & 24 & 19.6 & $63.02^{* *}$ \\
Feeding treatments & 3 & 0.942 & $3.03^{*}$ \\
\hline Interaction & 72 & 0.194 & $0.624^{\text {ns }}$ \\
Error & 1900 & 0.311 & \\
\hline
\end{tabular}

For summarizing the results of (FA), we use an index of (FA) across traits and the results of t-test were shown in figure (2 and 3 ). This index is composite fluctuating asymmetry.

The results of composite (FA) indicated that feeding treatments did not affect wing angels in worker bees, but it has an effect on veins distance, as feeding with sugar cane caused significant higher (FA) than with feeding with honey.

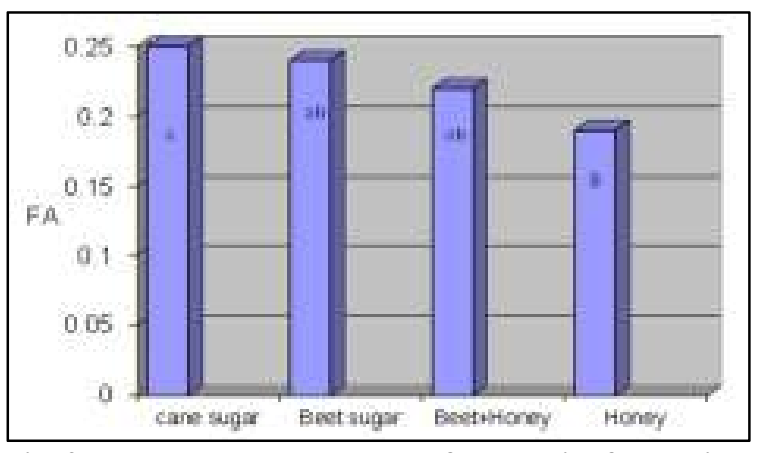

Fig. 2. Workers average values of composite fluctuating asymmetry in veins distances of forewing in different treatments (similar letters indicate nonsignificant)

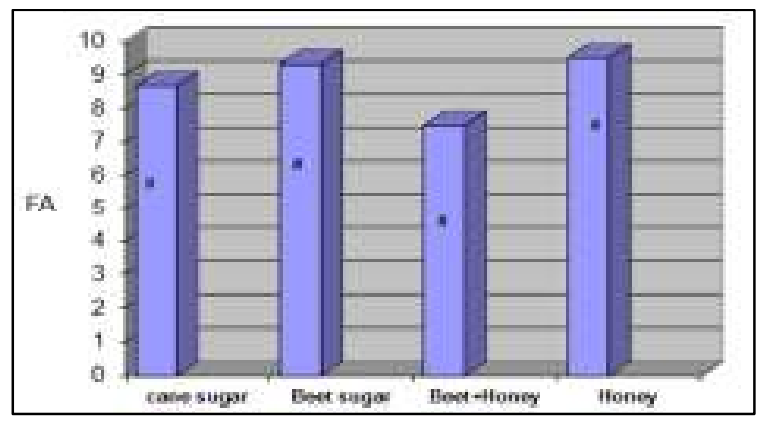

Fig. 3. Workers average values of composite fluctuating asymmetry in veins angels of forewing in different treatments 
In this study we investigate the influence of artificial feeding in comparison to honey-fed colonies on the degree of symmetry between right and left wing of honeybees, as many researches established that the use of wings seems to be effective in measuring developmental instability in many insects (Parsons and Hoffmann 1991; Imasheva et al. 1997; De Block and Stoks 2007; Berggren and Low 2009; Mazeed 2012; Mazeed, et al. 2015).

The presence of directional asymmetry of honeybee wings was demonstrated in some studies (Smith, et al. 1997; Schneider et al. 2003), but in most of them it was not significant (Clarke and Oldroyd 1996; Clarke 1997; Clarke, 1998; Jones et al. 2005; Ondo Zue Abaga et al. 2011).

In our results, only 3 forewing characters in sugar cane fed-colonies and one character in sugar beet fedcolonies showed significant directional asymmetry after bonferonii correction of significance level, so, it could be concluded that (DA) is less associated with the type of feeding under study. This result is in agree with that of (Mazeed, et al. 2015), who found that (DA) was not related to the type of food. It was earlier suggested that directional asymmetry is genetically determined and adaptive (VanValen, 1962; Windig \& Nylin, 1999), therefore, it should not be used as a measure of developmental stability (Palmer and Strobeck 1992).

As the results of (FA) analysis indicated, the (FA) differed significantly between all wing characters across feeding treatments, so, some traits are repeatably less stable developmentally than others. Also the four treatments had different effect on the fluctuating asymmetry of the pooled characters, suggesting that the level of developmental stability varies among feeding groups. The non-significant of the interaction indicated that, the variation of (FA) of the traits do not depend on feeding type, and all traits are the same at revealing presumed differences in developmental stability among samples.

It was suggested that some of these differences between characters may result from the fact that the impact of stress on fluctuating asymmetry seems to be trait- or stressor-specific (Beasley, et al. 2013) or simply be a consequence of their under sampling (Babbitt, et al. 2006).

According to the results of composite asymmetry, the vein distances of workers are more sensitive to the treatments than vein angles and caused higher (FA) values when feeding on cane sugar than feeding with honey.

Fluctuating asymmetry has already been used as a measure of developmental stability in honeybees. It was found that drones are more asymmetrical than workers (Brueckner 1976, but see Clarke 1997). Fluctuating asymmetry was also used in bee studies of rearing temperature (Jones et al. 2005), inbreeding (Brueckner 1976; Clarke, et al. 1986) and hybridization (Smith, et al. 1997) or even toxicity (Ondo Zue Abaga et al., 2011). However, the results of these studies are inconsistent, and some failed to demonstrate detectable changes in the level of fluctuating asymmetry (Jones et al. 2005; Smith, et al. 1997; Clarke, et al. 1986) while others did (Brueckner, 1976; Ondo Zue Abaga et al., 2011).

Few Studies had dealt with the impact of feeding on the (FA) of members of honeybee colonies. (Mazeed, et al. 2015) stated that sugar feeding caused significantly higher
FA in comparison to feeding with honey, and this effect was not influenced by neither the time of year nor the genotype of the colonies. Szentgyörgyi, et al. (2016), stated that, limited access to pollen caused some differences in the fluctuating asymmetry of size and shape in pollen-deprived workers and drones compared to the control bees, and there are more pronounced differences in (FA) due to replication than to pollen deprivation itself. They also reported that, malnutrition is a strong stressor affecting development and can cause changes in various morphological traits. One of these traits is the body symmetry of an organism.

In all mentioned (FA)'s Studies, the researchers aimed to study the effect of specific factor on the value of (FA) to investigate if a factor could be considered as a parameter for the existence of FA. Only few studies are dealing with the biological meaning of the presence of FA in terms of its effect on specific behavior, such as (Jaffé and Moritz, 2010) who stated that wing (FA) was found to be significantly lower in the drones collected at the drone congregation areas than in those collected from the hives. They concluded that a strong selective pressure may act on drones to ensure that queens in the congregation areas would mate with high quality drones. So, as reported by (Harvey And Walsh 1993; De Block and Stoks 2007), individuals with more symmetric wings may have a higher mating success due to flight mechanistic reasons as suggested in damselfly

Comparing the chemical composition of sugar cane with honey, it could be detected that the sugar cane has only one type of sugar, sucrose, in comparison with honey which has many types of sugars, amino acids, minerals, enzymes, hormones, vitamins, organic acids, and natural antibiotics in its components (Herold, 1982). So, sucrose syrup as artificial feeding might be one of nutritional stresses which are responsible of development instability (Polak, 1993). However, most of beekeepers cannot dispense with using artificial sugar feeding to feed their colonies, since it is used to supplement a shortage of stored honey to prevent starvation of the colony, or to stimulate a colony to artificially promote breeding. Accordingly, more studies are needed in order to find any deleterious effect of the presence of (FA) and other abnormal behavior on workers when feeding continuously with sugar cane in order to determine if (FA) had a biological meaning for bees or it would be only used as a marker to distinguish colonies being fed with artificial sugar syrup.

\section{REFERENCES}

Babbitt, G. A., Kiltie, R., \& Bolker, B. (2006). Are fluctuating asymmetry studies adequately sampled? Implications of a new model for size distribution. The American Naturalist, 167(2), 230-245. https:// doi.org/10.1086/498621

Beasley, D. A. E., Bonisoli-Alquati, A., \& Mousseau, T. A. (2013). The use of fluctuating asymmetry as a measure of environmentally induced developmental instability: A meta-analysis. Ecological Indicators, 30, 218-226. https://doi.org/ 10.1016/j.ecolind. 2013. 02.024 
Berggren, Å., \& Low, M. (2009). The Relationship Between Morphological Symmetry and Immune Response in Wild-Caught Adult Bush-Crickets. Symmetry, 1(2), 106-114. https://doi.org/ 10.3390/ sym 1020106

Bjorksten, T., David, P., Pomiankowski, A., \& Fowler, K. (2000). Fluctuating asymmetry of sexual and nonsexual traits in stalk-eyed flies: a poor indicator of developmental stress and genetic quality. Journal of Evolutionary Biology, 13(1), 89-97. https://doi.org/10.1046/j.1420-9101.2000.00146.x

Brueckner, D. (1976). The Influence of Genetic Variability on Wing Symmetry in Honey Bees Apis mellifera. Evolution, 30(1), 100-108. https://doi.org/ 10.1111/ j.1558-5646.1976.tb00886.x

Chengcheng, L., Xu, B., Wang, Y., Yang, Z., \& Yang, W. (2014). Protein content in larval diet affects adult longevity and antioxidant gene expression in honey bee workers. Entomologia Experimentalis et Applicata, 151(1), 19-26. https://doi.org/ 10.1111/ eea. 12167

Clarke, G. M. (1997). The genetic basis of developmental stability. III. Haplo-diploidy: are males more unstable than females? Evolution, 51(6), 20212028. https://doi.org/10.2307/2411023

Clarke, G. M. (1998). The genetic basis of developmental stability. IV. Individual and population asymmetry parameters. Heredity, 80(5), 553-561. https:// doi.org/ 10.1046/j.1365-2540.1998.00326.x

Clarke, G. M., Brand, G. W., \& Whitten, M. J. (1986). Fluctuating asymmetry: A technique for measuring developmental stress caused by inbreeding. Australian Journal of Biological Sciences, (00049417). Retrieved from http://agris.fao.org/agrissearch/search.do?recordID=US201301419140

Clarke, G. M., \& McKenzie, L. J. (1992). Fluctuating Asymmetry as a Quality Control Indicator for Insect Mass Rearing Processes. Journal of Economic Entomology, 85(6), 2045-2050. https:// doi.org/ 10.1093/jee/85.6.2045

Clarke, G. M., \& Oldroyd, B. P. (1996). The genetic basis of developmental stability in Apis mellifera II. Relationships between character size, asymmetry and single-locus heterozygosity. Genetica, 97(2), 211-224. https://doi.org/10.1007/BF00054628

Daly, H. V, Danka, R. G., Hoelmer, K., Rinderer, T. E., \& Buco, S. M. (1995). Honey bee morphometrics: linearity of variables with respect to body size and classification tested with European worker bees reared by varying ratios of nurse bees. Journal of Apicultural Research, 34(3), 129-145. https:// doi.org/ 10.1080/00218839.1995.11100898

DeBlock, M., \& Stoks, R. (2007). Flight-related body morphology shapes mating success in a damselfly. Animal Behaviour, 74(4), 1093-1098. https:// doi.org/ 10.1016/ j.anbehav.2007.01.023

Field, S. A., \& Yuval, B. (1999). Nutritional status affects copuladuration in the Mediterranean fruit fly,Ceratitis capitata(Insecta:Tephritidae). Ethology Ecology and Evolution, 11, 61-70.
Foley, K., Fazio, G., Jensen, A. B., \& Hughes, W. O. H. (2012). Nutritional limitation and resistance to opportunistic Aspergillus parasites in honey bee larvae. Journal of Invertebrate Pathology, 111(1), 68-73. https://doi.org/10.1016/j

HARVEY, I. F., \& WALSH, K. J. (1993). Fluctuating asymmetry and lifetime mating success are correlated in males of the damselfly Coenagrion puella (Odonata: Coenagrionidae). Ecological Entomology, 18(3), 198-202. https://doi.org /10.1111/ j.1365-2311.1993.tb01090.x

Herold, E. (1982). Heilwerte aus dem Bienenvolk. Ehrenwirth Verlag, Muenchen.

Holm, K. (2015). Almo-Statistik-System. Univ. Linz, Austria.

Imasheva, A. G., Loeschcke, V., Zhivotovsky, L. A., \& Lazebny, O. E. (1997). Effects of extreme temperatures on phenotypic variation and developmental stability in Drosophila melanogaster and Drosophila buzzatii. Biological Journal of the Linnean Society, 61(1), 117-126. https:// doi.org/ 10.1111/j.1095-8312.1997.tb01780.x

Jaffé, R., \& Moritz, R. F. A. (2010). Mating flights select for symmetry in honeybee drones (Apis mellifera). Naturwissenschaften.https://doi.org/10.1007/s0011 4-009-0638-2

Jones, J. C., Helliwell, P., Beekman, M., Maleszka, R., \& Oldroyd, B. P. (2005). The effects of rearing temperature on developmental stability and learning and memory in the honey bee, Apis mellifera. Journal of Comparative Physiology A, 191(12), 1121-1129. https://doi.org/10.1007/s00359-0050035-Z

Kauhausen, D. (2002). Methods of classification of honeybee races using wing characters. 2nd European Scientific Apiculture Conference, Balatonlelle, Hungary., 47(1), 103-107. Retrieved from http://www. jas.org.pl/ Methods -ofclassification- of- honeybee-races-using-wingcharacters-a-review, $0,157 . \mathrm{html}$

Leung, B., Forbes, M. R., \& Houle, D. (2000). Fluctuating Asymmetry as a Bioindicator of Stress: Comparing Efficacy of Analyses Involving Multiple Traits. The American Naturalist, 155(1), 101-115. https:// doi.org/ 10.1086/303298

Li, J., Wang, T., Zhang, Z., \& Pan, Y. (2007). Proteomic Analysis of Royal Jelly from Three Strains of Western Honeybees ( Apis mellifera ). Journal of Agricultural and Food Chemistry, 55(21), 84118422. https://doi.org/10.1021/jf0717440

Mazeed, A. M. (2012). Anomalies and asymmetry of wing venation pattern in Carniolan and Egyptian bee populations in Egypt. Egyptian Academic Journal of Biological Science, 4(1), 149-161. https://doi.org/10.21608/eajbsa.2011.15180

Mazeed, A. M., Fawzy, A. M., \& Nafea, E. A. (2015). Wing symmetry as affected by artificial feeding in honeybees colonies. In the 5th International Conference of Plant Protection Research Institute. May 3-6, Al-Hurghada, Egypt, (pp. 753-765). 
Møller, A, P., \& Thornhill, R. (1998). Bilateral symmetry and sexual selection: a meta-analysis. The American Naturalist, 151(2), 174-192. https:/ /doi.org/ 10.1086/286110

Neupane, K., \& Thapa, R. (2005). Alternative to OffSeason Sugar Supplement Feeding of Honeybees. Journal of the Institute of Agriculture and Animal Science, 26(0), 77. https:// doi.org/ 10.3126/ jiaas. v26i0.615

Ondo Zue Abaga, N., Alibert, P., Dousset, S., Savadogo, P. W., Savadogo, M., \& Sedogo, M. (2011). Insecticide residues in cotton soils of Burkina Faso and effects of insecticides on fluctuating asymmetry in honey bees (Apis mellifera Linnaeus). Chemosphere, 83(4), 585-592. https:// doi.org/10.1016/j.chemosphere.2010.12.021

Palmer, A. R. (1994). Developmental Instability: Its Origins and Evolutionary Implications. Developmental instability: Its origins and evolutionary implications (Vol. 2). https:// doi.org/ 10. 1007/978-94-011-0830-0

Palmer, A. R., \& Strobeck, C. (1986). Fluctuating Asymmetry: Measurement, Analysis, Patterns. Annual Review of Ecology and Systematics, 17(1), 391-421.https:// doi.org/ 10.1146/ annurev.es. 17. 110186. 002135

Palmer, A. R., \& Strobeck, C. (1992). Fluctuating asymmetry as a measurement of developmental stability: Implications of non-normal distributions and power of statistical tests. Acta Zoologica Fennica, 191, 57-72.

Palmer, R., \& Strobeck, C. (2003). Fluctuating asymmetry analyses revisited. In: Polak, M. (ed.) Developmental Instability (DI): Causes and Consequences. Oxford University Press, Oxford, 279-319.

Parsons, P., \& Hoffmann, A. A. (1991). Evolutionary genetics and environmental stress - Ary A. Hoffmann, Peter Angas Parsons- book Google. Oxford Science Publications, Oxford. Retrieved from https:// books.google.com.eg/ books/about/ Evolutionary_genetics_and_environmental.html?id $=$ xmTwAAAAMAAJ\&redir_esc $=y$

Polak, M. (1993). Parasites increase fluctuating asymmetry of maleDrosophila nigrospiracula: Implications for sexual selection. Genetica, 89(1-3), 255-265. https://doi.org/10.1007/BF02424519
Rantala, M., Jari, A., \& Suhonen, J. (2004). Fluctuating Asymmetry and Immune Function in a Field Cricket. Oikos. WileyNordic Society Oikos. https://doi.org/10.2307/3548234

Schmid-Hempel, P. (2003). Variation in immune defence as a question of evolutionary ecology. Proceedings of the Royal Society B: Biological Sciences. https://doi.org/10.1098/rspb.2002.2265

Schneider, S. S., Leamy, L. J., Lewis, L. A., \& DeGrandiHoffman, G. (2003). The influence of hybridization between African and European honeybees, Apis mellifera, on asymmetries in wing size and shape. Evolution. https://doi.org/10.1111/j.0014-3820. 2003. tb00247.x

Smith, D. R., Crespi, B. J., \& Bookstein, F. L. (1997). Fluctuating asymmetry in the honey bee, Apis mellifera: effects of ploidy and hybridization. Journal of Evolutionary Biology, 10(4), 551-574. https://doi.org/10.1046/j.14209101.1997.10040551.x

Sokal, R. R., \& Rohlf, F. J. (1995). Biometry: The Principles and Practice of Statistics . Biological Research 3rd Edition, W.H. Freeman and Co., New York.

Szentgyörgyi, H., Czekońska, K., \& Tofilski, A. (2016). Influence of pollen deprivation on the fore wing asymmetry of honeybee workers and drones. Apidologie. https://doi.org/10.1007/s13592-0150415-5

Szymula, J., Skowronek, W., \& Bienkowska, M. (2010). Use of various morphomerical traits measured by microscope or by computer methods in the honeybee taxonomy. J. Apic. Sci., 54, 91-97.

VanValen, L. (1962). A Study of Fluctuating Asymmetry. Evolution, 16(2), 125. https:// doi.org/ 10.2307/ 2406192

Whitlock, K. E. (1993). Development of Drosophila wing sensory neurons in mutants with missing or modified cell surface molecules. Development (Cambridge, England), 117(4), 1251-1260. Retrieved from http:// www. ncbi.nlm.nih.gov/ pubmed/ 8404529

Windig, J. J., \& Nylin, S. (1999). Adaptive wing asymmetry in males of the speckled wood butterfly (Pararge aegeria)? Proceedings of the Royal Society B: Biological Sciences, 266(1427), 14131418. https://doi.org/10.1098/rspb.1999.0795

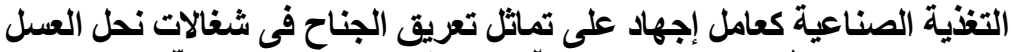

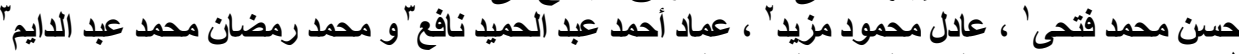

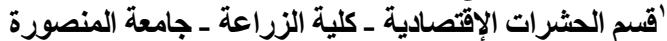

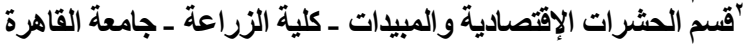

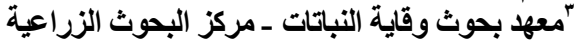

نم تقدير صفة عدم التماتل ذو الاتجاه الواحد وذو الاتجاهين فى الجناح الامامى لشغالات نحل العسل التىى تم تغذيتها بمحاليل سكريه مختلفه و مقارنتها

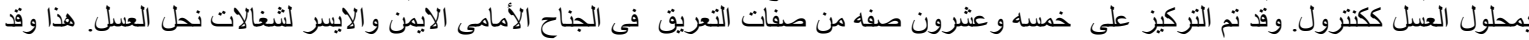

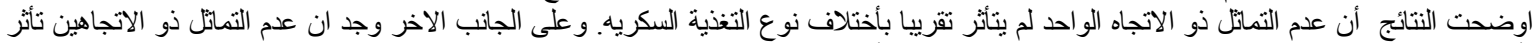

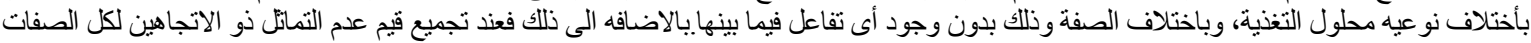

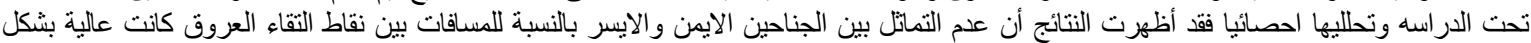
معنوى فى التغذية السكرية بقصب السكر عن التغذية بالعسل .
} 